\title{
Analisis Pengaruh Perkembangan Identitas Terhadap Intensi Turnover Dengan Mediasi Komitmen Karier Pada Karyawan Milenial Jabodetabek
}

\author{
Timothy Tedja ${ }^{1}$, Rosdiana Sijabat $^{2}$
}

${ }^{1}$ Universitas Pelita Harapan

The Plaza Semanggi, Jl. Jend. Sudirman No.50, Jakarta, Indonesia

${ }^{2}$ Unika Atma Jaya

Jl. Jenderal Sudirman No. 51, Jakarta, Indonesia

e-mail: ${ }^{1} 01619190079 @$ student.uph.edu, ${ }^{2}$ rosdiana.sijabat@ atmajaya.ac.id

\begin{tabular}{llll}
\hline Informasi Artikel & Diterima: 08-07-2021 & Direvisi: 23-07-2021 & Disetujui: 27-07-2021 \\
\hline
\end{tabular}

\begin{abstract}
Abstrak
Tujuan penelitian ini adalah untuk mengetahui: 1) pengaruh keberhasilan perkembangan identitas terhadap identitas karier, 2) perencanaan karier, dan 3) resiliensi karier, 4) pengaruh identitas karier, 5) perencanaan karier, dan 6) resiliensi terhadap intensi turnover, 7) pengaruh keberhasilan perkembangan identitas terhadap intensi turnover, serta pengaruh keberhasilan perkembangan identitas terhadap intensi turnover dengan (8) identitas karier, (9) perencanaan karier, dan (10) resiliensi karier sebagai mediasi. Penemuan dari riset ini adalah keberhasilan perkembangan identitas memiliki pengaruh positif terhadap identitas karier, perencanaan karier, dan resiliensi karier. Perencanaan karier dan resiliensi karier memiliki pengaruh positif terhadap intensi turnover. Keberhasilan perkembangan identitas memiliki pengaruh positif terhadap intensi turnover dengan mediasi perencanaan karier dan resiliensi karier. Kontribusi dari riset ini dapat memberikan masukan bagi organisasiorganisasi yang ada di Jabodetabek untuk mengurangi intensi turnover.
\end{abstract}

Kata Kunci: Perkembangan Identitas; Idetitas Karier; Perencanaan Karier; Resiliensi Karier; Intensi Turnover

\begin{abstract}
The purposes of this study are to determine: 1) The effect of successful identity development on career identity, 2) career planning, and 3) career resilience, 4) The effect of career identity, 5) career planning, and 6) career resilience on turnover intention, 7) The effect of successful identity development on turnover intention, and the effect of successful identity development on turnover intention with (8) career identity, (9) career planning, and (10) career resilience as mediatior. The findings of this research are that successful identity development has a positive effect on career identity, career planning, and career resilience. Career planning and career resilience have a positive effect on turnover intention. Successful identity development has a positive effect on turnover intention by career planning and career resilience as mediator. The contribution of this research can provide input for organizations in Greater Jakarta to reduce turnover intention.
\end{abstract}

Keywords: Identity Development; Career Identity; Career Planning; Career Resilience; Intention Turnover

\section{Pendahuluan}

Berdasarkan penelitian yang dilakukan oleh IDN Research Institute dan Alvara Research Center pada tahun 2018 (dalam Folia, 2020) disimpulkan bahwa milenial memiliki loyalitas yang rendah terhadap perusahaan karena rata-rata milenial bertahan hanya sekitar dua hingga tiga tahun di satu perusahaan. Bukan hanya satu penelitian saja yang menyimpulkan mengenai isu loyalitas millennial yang rendah, penelitian lainnya juga menyatakan hal yang serupa. Penelitian serupa yang dilakukan oleh Jobplanet pada tahun 2017 (dalam Apriyono, 2017) menyimpulkan bahwa millennial memiliki loyalitas terhadap perusahaan yang rendah karena dalam penelitian tersebut sebanyak $76,7 \%$ millennial bekerja hanya satu hingga dua tahun sebelum berpindah kerja.

Selain fenomena milenial yang sering berpindah kerja tersebut, penelitian ini juga membahas fenomena lainnya yang merupakan fenomena keterlambatan perkembangan identitas. Pada saat ini terdapat fenomena identitas yang berkembang terlambat (Lally \& Valentine-French, 2017). Identitas yang seharusnya berkembang pada umur 12-18 tahun berkembang terlambat hingga emerging adulthood di rentang umur yang dinamakan prolonged adolescence (Erikson dalam Lally \& Valentine-French, 2017). Berdasarkan 
Society for the Study of Emerging Adulthood (2016) rentang umur emerging adulthood berkisar saat umur 18 hingga 29 tahun. Tahapan perkembangan identitas tersebut terjadi dalam tahapan psychosocial stage identity vs. role confusion yang diteorikan oleh Erikson dalam Lally dan Valentine-French (2017).

Kedua fenomena di atas berhubungan berdasarkan penelitian yang pernah dilakukan. Berdasarkan hasil penelitian Deng et al., (2021) perkembangan identitas okupasional, yang merupakan pengukuran identitas yang didasarkan perkembangan identitas Erikson, berpengaruh secara negatif terhadap intensi turnover. Kemungkinan hubungan antar dua fenomena di atas diperkuat dengan beberapa pendapat ahli di bawah ini.

Keterlambatan perkembangan identitas menurut Donoughue (2017) disebabkan seringnya penggunaan internet dan media sosial karena menjadikan individu semakin memerlukan banyak waktu untuk mengembangkan identitas. Apalagi berdasarkan penelitian oleh Indonesia Millenial Report dalam Deloitte Indonesia Perspectives (2019) ditemukan bahwa hampir seluruh milenial telah terkoneksi dengan internet, bahkan sebagian besar dari mereka mengalami kecanduan atau ketergantungan internet. Bahkan Wisnu dalam Tim Website UNY (2017) menjelaskan lebih lanjut bahwa seringnya penggunaan internet dan media sosial tersebut menyebabkan individu sulit menemukan serta mempertahankan identitasnya. Padahal dalam penelitian Ross (2017) dinyatakan bahwa perkembangan identitas yang baik dapat membantu seseorang dalam menentukan pilihan kariernya

Penelitian serupa mengenai perkembangan identitas dalam penelitian yang dilakukan oleh Nauta dan Kahn (2007); Schwartz et al. (2005); Schwartz et al. (2009); Vondracek et al. (1995), menemukan bahwa kesulitan menentukan karier disebabkan oleh perkembangan identitas yang tidak baik. Bahkan hasil penelitian Grotevant dan Thorbecke (1982) menyimpulkan jika keberhasilan perkembangan identitas berkorelasi dengan komitmen karier. Penelitian tersebut mendukung pernyataan Trisnawati (2012), bahwa perkembangan identitas seseorang yang tidak baik akan menyebabkan orang tersebut belum mantap dalam menentukan karier sehingga cenderung berpindahpindah dari suatu pekerjaan ke pekerjaan lainnya.

Oleh karena studi sebelumnya tersebut menyatakan adanya korelasi antar perkembangan identitas dengan komitmen karier, maka diperlukan pembahasan lebih lanjut mengenai komitmen karier. Ingarianti et al. (2019) mendefinisikan komitmen karier sebagai perilaku, sifat dan motivasi yang ditunjukkan seseorang pada sebuah profesi dalam bertahan dan menjalani karier yang dipilih. Berdasarkan Ingarianti et al. (2019) penentuan karier yang disebut sebagai komitmen karier dapat menyebabkan seseorang tetap bekerja di suatu organisasi terlepas dari rekan sepekerja, kondisi kerja, maupun ketidakpuasan organisasi tempat ia bekerja. Secara lebih jelas Bedeian et al. (1991); Blau (1989) menyatakan bahwa komitmen karier berkorelasi negatif dengan turnover. Komitmen karier juga dinyatakan lebih efektif serta stabil (Jauch, Glueck, \& Osborn; Steel \& Ovalle dalam Carson, 1991), mengenerasi output yang lebih tinggi (Taylor; Roethlisberger \& Dickson, dalam Carson, 1991), serta berdampak pada kesuksesan karier yang terdiri dari tingkat gaji dan kepuasan karier (Ballout dalam Ingarianti et al., 2019); (Lakshmi \& Sumaryono, 2019).

Salah satu faktor yang erat dengan komitmen karier adalah intensi turnover. Meyer et al. (2002) menjelaskan intensi turnover sebagai keinginan yang sengaja serta sadar untuk meninggalkan organisasi untuk mencari peluang kerja di organisasi lain. Dalam salah satu penelitian yang dilakukan oleh Porter dan Steers dalam Li (2018) komitmen karier dinyatakan memiliki peristensi dan integritas yang besar dalam memprediksi Intensi turnover. Berdasarkan $\mathrm{Li}$ (2018) karyawan yang memiliki komitmen karier akan lebih mengejar kemungkinan-kemungkinan untuk mengembangkan kariernya sehingga akan mencapai ekspektasi kariernya di organisasi tempat ia bekerja, sebaliknya karyawan yang memiliki komitmen karier yang rendah akan meninggalkan organisasi tempatnya bekerja saat ini karena organisasi menyediakan area karier yang tidak dikomitmenkan karyawan tersebut. Ingarianti et al. (2019) menyatakan hal yang serupa bahwa bahwa komitmen karier menyebabkan individu dapat tetap bekerja di suatu organisasi terlepas dari kondisi kerja, rekan sepekerja, dan bahkan rasa tidak puas terhadap organisasi tempat individu bekerja.

Salah satu alat ukur yang mengukur mengenai komitmen karier adalah The Commitment Career Measure (CCM). Commitment Career Measure (CCM) ini dikembangkan oleh Carson dan Bedeian dan dinyatakan lebih dapat mengukur semua varian dalam konstruk komitmen karier dibandingkan alat ukur lainnya (dalam Ingarianti et al, 2019). Komitmen karier memiliki tiga dimensi yang adalah dimensi identitas karier yang merupakan hubungan emosional individu dengan karier yang dipilih, dimensi perencanaan karier yang merupakan proses penentuan kebutuhan perkembangan karier dan penetapan tujuan kariernya, dan dimensi resiliensi karier yang merupakan ketekunan dalam mencapai tujuan karier (Carson \& Bedeian dalam Ingarianti et al, 2019).

Alat ukur yang digunakan untuk mengukur perkembangan identitas adalah Identity vs. role confusion Erikson psychosocial stage inventory (EPSI). Alat ukur tersebut dipilih karena originalitasnya dalam mengukur perkembangan identitas Erikson. Pengukuran Identity vs. role confusion EPSI dinilai telah menangkap makna dan 
kompleksitas psychosocial stage karena alat ukur ini mengukur keberhasilan perkembangan identitas Erikson yang terdiri dari enam penyelesaian keberhasilan dan enam penyelesaian kegagalan dari tahapan krisis (Rosenthal et al., 1981).

Selain itu alat ukur yang digunakan dalam pengukuran intensi turnover bernama alat ukur intensi turnover. Alat ukur intensi turnover menunjukkan ukuran kuat atau lemahnya intensi untuk keluar dari organisasi saat ini ke organisasi lain dan terdiri dari tiga dimensi; dimensi adanya pikiran untuk keluar dari organisasi, dimensi intensi mencari pekerjaan di tempat lain, dan dimensi intensi untuk keluar meninggalkan perusahaan (Mulyapradana, 2012).

Penelitian-penelitian dan pendapat ahli di atas menjadikan pentingnya agar penelitian mengenai identitas dan komitmen karier dilakukan karena belum pernah dilakukan sebelumnya.

Beberapa penelitian terdahulu menyatakan pengaruh antar komitmen karier dan intensi turnover. Dalam berbagai penelitian terdapat pembuktian bahwa komitmen karier mempengaruhi intensi turnover secara negatif (Bedeian et al., 1991); (Li, 2018). Jauch, Osborn, dan Terpening (1980) dalam Bedeian et al. (1991) menyatakan bahwa karier komitmen dapat digunakan untuk memprediksi intensi turnover karena komitmen terhadap karier adalah hasil dari identifikasi dengan organisasi dan teman sepekerja.

Penelitian sebelumnya sejalan dengan pernyataan ahli, bahwa komitmen karier menyebabkan seseorang dapat tetap bekerja di suatu organisasi terlepas dari rekan sepekerja, kondisi kerja, maupun ketidakpuasan organisasi tempat ia bekerja (Ingarianti et al., 2019). Hal tersebut disebabkan oleh karena lima fokus dari komitmen karier adalah etika kerja, keterlibatan kerja, komitmen organisasi, komitmen serikat kerja, serta komitmen karier pada pekerjaan di organisasi tempat seseorang bekerja (Ingarianti et al., 2019). Bahkan komitmen karier dapat menyebabkan seseorang terikat dengan pekerjaannya walaupun tidak puas dengan pekerjaannya tersebut karena seseorang tersebut menganggap pekerjaan tersebut relevan terhadap kariernya (Mobley dalam Bedeian et al., 1991).

Penelitian lainnya yang diteliti Li (2018) menemukan bahwa komitmen karier berperan sebagai variabel mediasi pada pengaruh pertumbuhan karier terhadap intensi turnover, serta sebagai variabel moderator; semakin tingginya komitmen karier maka semakin tinggi juga pengaruh pertumbuhan karier terhadap intensi turnover. $\mathrm{Li}$ (2018) juga menekankan bahwa komitmen karier dapat digunakan sebagai kriteria evaluasi dalam oganisasi karena atasan dapat menyesuaikan keputusan mengenai praktek-praktek sumber daya manusia dengan mengetahui tingkat komitmen karier anggota organisasi.
Penelitian yang dilakukan oleh Ingarianti et al. (2019) menyatakan bahwa penentuan karier yang disebut sebagai komitmen karier dapat menyebabkan seseorang tetap bekerja di suatu organisasi terlepas dari rekan sepekerja, kondisi kerja, maupun ketidakpuasan organisasi tempat ia bekerja. Grotevant dan Thorbecke (1982) juga menyatakan hal serupa dengan menggunakan alat ukur perkembangan identitas berupa status identitas yang didasarkan teori identitas Erikson, menyatakan bahwa keberhasilan perkembangan identitas berkorelasi dengan komitmen karier. Penelitian sebelumnya tersebut sejalan dengan pernyataan ahli, bahwa perkembangan identitas seseorang yang tidak baik akan menyebabkan orang tersebut belum mantap dalam menentukan karier (Trisnawati, 2012).

Dalam penelitian Deng et al. (2020) identitas okupasional yang diformulasikan berdasarkan konsep perkembangan identitas Erikson berpengaruh secara negatif terhadap intensi turnover. Hasil penelitian tersebut dapat dijelaskan dengan dua teori. Bahwa saat individu memiliki identitas yang konsisten dengan karirnya, mereka akan mencurahkan lebih banyak energi dan lebih bersemangat untuk bekerja, sehingga ketidakpuasan yang disebabkan oleh lingkungan kerja akan dihilangkan sampai batas tertentu (Sabanciogullari \& Dogan, 2015). Selain itu individu dapat mempertahankan tingkat keterlibatan kerja yang tinggi, terlepas dari baik atau buruknya kondisi kerja, jika aspek-aspek dari identitas individu tersebut konsisten dengan pekerjaannya (Britt, 2003).

\section{Keberhasilan perkembangan identitas}

Berdasarkan Muss ( dalam Karcher \& Benne, 2007), tahapan perkembangan identitas Erikson didefinisikan sebagai tahapan di mana individu berusaha untuk menemukan kelanjutan hidup dengan mengeksplorasi dan merefleksikan dirinya pada masa lalu, sekarang, dan masa depan. Sepanjang masa hidup seseorang perkembangan identitas adalah tugas pengembangan yang paling utama (Erikson dalam Karaś et al., 2014). Jika individu melewati tahapan perkembangan ini dengan tidak baik maka individu akan bingung perihal siapa dirinya, di mana dirinya harus berada dan dimana dirinya akan pergi, namun jika individu melewati tahapan perkembangan ini dengan baik akan memperoleh identitas diri untuk meghadapi kedewasaan (Schultz \& Schultz, 2009).

Perkembangan identitas berlangsung pada tahapan Identity vs. Role Confusion dalam psychosocial stages. Psychosocial stages diteorikan oleh Erikson (dalam Lally \& Valentine-French, 2017), terdiri dari delapan tahapan perkembangan manusia dan membentuk perkembangan sosial serta emosional seseorang. 


\section{Komitmen Karier}

Blau (dalam Carson, 1991) menyatakan bahwa motivasi karier yang diteorikan oleh London dijadikan landasan teoretis bagi komitmen karier. Hal tersebut disebabkan oleh karena motivasi karier yang memiliki definisi sebagai kekuatan motivasi seseorang untuk bekerja di karier yang telah dipilihnya (Hall dalam Carson, 1991). Berdasarkan teori London (dalam Ingarianti et al., 2019) tiga faktor utama dari komitmen karier ditentukan terdiri dari:

1. Identitas karier: Hubungan emosional dengan pilihan karier. London dan Noe (1997) menjelaskannya sebagai sejauh mana seseorang mendefinisikan dirinya sendiri dengan pekerjaannya. 2. Perencanaan karier: Penentuan kebutuhan perkembangan dan tujuan karier. London dan Noe (1997) menjelaskannya sebagai kemampuan untuk bersikap realistis tentang diri dan kariernya, serta menggunakan persepsi tersebut untuk digunakan dalam menetapkan tujuan karier.

3. Resiliensi karier: Sejauh mana ketekunan dalam pencapaian tujuan karier. London dan Noe (1997) menjelaskannya sebagai kemampuan dalam beradaptasi dengan perubahan, bahkan ketika keadaan mengecilkan hati atau disruptif.

Berdasarkan definisi tersebut, secara operasional komitmen karier berbeda dari keterlibatan kerja dan komitmen organisasi (Blau, 1989). Secara konseptual komitmen karier berbeda dengan komitmen organisasi, komitmen karier merupakan sikap terhadap profesi atau pekerjaan (Blau dalam Ingarianti, 2017) sedangkan komitmen organisasi merupakan tingkat identifikasi dan keterlibatan terhadap organisasi (Hellriegel \& Slocum dalam Ingarianti, 2017).

Dengan mengacu penelitian sebelumnya yang menggunakan variabel komitmen karier ( dalam Wilson et al., 2016), analisa komitmen karier dilakukan dengan menggunakan ketiga dimensi dari variabel komitmen karier sebagai variabelnya yang adalah perencanaan karier, identitas karier dan resiliensi karier. Wilson et al. (2016) menambahkan bahwa secara bersama-sama tiga dimensi tersebut berkontribusi terhadap pemahaman yang mendalam bagi komitmen karier.

\section{Intensi turnover}

Intensi turnover dinyatakan sebagai prediktor yang paling baik dari turnover itu sendiri (Mulyapradana, 2012). Intensi turnover didefinisikan sebagai keinginan yang penuh pertimbangan serta sadar untuk meninggalkan organisasi (Meyer et al., 2002); (Mulyapradana, 2012).

Mobley (1977) menjelaskan bahwa dalam turnover atau keluar dari organisasi, seseorang mengalami beberapa tahapan. Tahapan tersebut adalah masalah akan ketidakpuasan dalam bekerja, berpikir untuk berhenti, lalu intensi untuk mencari pekerjaan lain, lalu intensi untuk keluar dari pekerjaan. Ketidakpuasan dalam bekerja meningkatkan munculnya pemikiran anggota organisasi untuk berhenti dari organisasi. Pemikiran tersebut menyebabkan langkah selanjutnya yang lebih nyata berupa intensi untuk mencari pekerjaan lainnya. Intensi tersebut menyebabkan anggota organisasi melakukan perbandingan antar pekerjaan di organisasi saat ini dengan organisasi di tempat lain. Perbandingan tersebut akan menyebabkan pengambilan keputusan dalam langkah selanjutnya yang berupa intensi untuk keluar dari pekerjaan.

\section{Hipotesis}

Dengan mengacu pada rumusan masalah, teori dan penelitian sebelumnya, maka hipotesis yang diajukan adalah sebagai berikut:

H1: Keberhasilan perkembangan identitas berpengaruh terhadap identitas karier pada karyawan milenial di Jabodetabek.

$\mathrm{H} 2$ : Keberhasilan perkembangan identitas berpengaruh terhadap perencanaan karier pada karyawan milenial di Jabodetabek.

H3: Keberhasilan perkembangan identitas berpengaruh terhadap resiliensi karier pada karyawan milenial di Jabodetabek.

H4: Identitas karier berpengaruh terhadap intensi turnover pada karyawan milenial di Jabodetabek.

H5: Perencanaan karier berpengaruh terhadap intensi turnover pada karyawan milenial di Jabodetabek.

H6: Resiliensi karier berpengaruh terhadap intensi turnover pada karyawan milenial di Jabodetabek.

H7: Keberhasilan perkembangan identitas berpengaruh terhadap intensi turnover pada karyawan milenial di Jabodetabek.

H8: Keberhasilan perkembangan identitas berpengaruh terhadap intensi turnover dengan mediasi identitas karier pada karyawan milenial di Jabodetabek.

H9: Keberhasilan perkembangan identitas berpengaruh terhadap intensi turnover dengan mediasi perencanaan karier pada karyawan milenial di Jabodetabek.

H10: Keberhasilan perkembangan identitas berpengaruh terhadap intensi turnover dengan mediasi resiliensi karier pada karyawan milenial di Jabodetabek.

Dengan mengacu pada hipotesis maka model penelitian yang diajukan adalah sebagai berikut : 


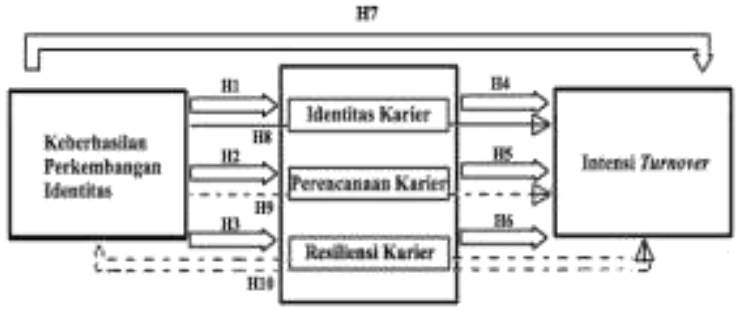

Gambar 1. Model Penelitian

\section{Metode Penelitian}

Secara studi, tipe penelitian ini adalah pengujian hipotesis. Pengujian hipotesis bertujuan untuk menguji hipotesis dan biasanya digunakan untuk mengetahui hubungan antar variabel (Suliyanto, 2006). Dalam penelitian ini hubungan antar variabel yang diteliti adalah pengaruh.

Untuk desain penelitian, pada penelitian berikut digunakan riset survei. Dalam penelitian riset survei penelitian menggunakan kuisioner yang dituju kepada sampel dari suatu populasi yang telah peneliti tentukan (Siyoto \& Sodik, 2015).

\section{Populasi dan sampel}

Kriteria yang berupa karyawan milenial di Jabodetabek di tentukan dalam penelitian ini berdasarkan fenomena perkembangan identitas yang terlambat (Erikson dalam Lally \& Valentine-French, 2017) yang akhir rentang umurnya bertepatan dengan awal rentang umur milenial. Pada tahun 2020 milenial berumur 25-40 tahun (Ekrut, 2020), karena penelitian ini dilakukan pada tahun 2021 maka rentang umur milenial menjadi 25-41 tahun. Peneliti memutuskan menggunakan populasi milenial berdasarkan penelitian sebelumnya. Berdasarkan IDN Research Institute dan Alvara Research Center pada tahun 2018 dalam Folia (2020); Jobplanet pada tahun 2017 (dalam Apriyono, 2017) milenial dinyatakan sering berpindah kerja.

Secara wilayah, kriteria yang bertempat tinggal di Jabodetabek (Jakarta, Bogor, Depok, Tangerang, dan Bekasi) ditentukan karena wilayah tersebut adalah wilayah urban. Wilayah didasarkan penelitian yang menyatakan bahwa di wilayah urban terdapat sebesar $72.41 \%$ penetrasi pengguna internet (APJII, 2017).

Untuk memastikan jumlah sampel penelitian, jumlah sampel perlu dipastikan berdasarkan acuan ahli. Berdasarkan Ringle (2018) dengan jumlah variabel independen hingga 50, dengan tingkat signifikansi $5 \%$, power $95 \%$, effect size 0.2 membutuhkan jumlah sampel minimum 72 , effect size 0.1 membutuhkan jumlah sampel minimum 134, sedangkan dengan effect size 0.05 membutuhkan jumlah sampel minimum 263. Maka untuk hasil terbaik jumlah sampel yang dituju peneliti adalah 134-263 sampel seturut acuan minimum tertinggi yang disarankan ahli.

Penentuan non probability sampling dengan teknik sampling insidential juga ditentukan dalam penelitian. Sampling insedential merupakan teknik pemenuhan jumlah sampel secara kebetulan atau acak berdasarkan karakteristik yang telah ditentukan (Latipah, 2012). Teknik ini digunakan karena efisiensi dan efektifitas dalam pemenuhan jumlah sampel yang diperlukan dalam penelitian karena jumlah sampel yang diperlukan cukup banyak, yaitu sebanyak 214 sampel.

\section{Hasil dan Pembahasan}

\section{Hasil Uji Hipotesis dan Kekuatan Pengaruh}

\begin{tabular}{|c|c|c|c|c|}
\hline & Hipotesis & $\beta$ & T Stat. & P Val. \\
\hline 1 & $\begin{array}{l}\text { Perkembangan } \\
\text { identitas -> Identitas } \\
\text { karier }\end{array}$ & 0.494 & 9.727 & 0.000 \\
\hline 2 & $\begin{array}{l}\text { Perkembangan } \\
\text { identitas -> } \\
\text { Perencanaan karier }\end{array}$ & 0.392 & 6.975 & 0.000 \\
\hline 3 & $\begin{array}{l}\text { Perkembangan } \\
\text { identitas } \\
\text { Resiliensi karier }\end{array}$ & 0.284 & 3.723 & 0.000 \\
\hline 4 & $\begin{array}{l}\text { Identitas karier } \quad-> \\
\text { Intensi turnover }\end{array}$ & -0.051 & 0.739 & 0.460 \\
\hline 5 & $\begin{array}{l}\text { Perencanaan karier - } \\
\text { > Intensi turnover }\end{array}$ & 0.221 & 3.062 & 0.002 \\
\hline 6 & $\begin{array}{l}\text { Resiliensi karier -> } \\
\text { Intensi turnover }\end{array}$ & 0.508 & 8.863 & 0.000 \\
\hline 7 & $\begin{array}{l}\text { Perkembangan } \\
\text { identitas -> Intensi } \\
\text { turnover }\end{array}$ & 0.135 & 2.021 & 0.044 \\
\hline 8 & $\begin{array}{l}\text { Perkembangan } \\
\text { identitas }->\text { Identitas } \\
\text { Karier -> Intensi } \\
\text { turnover }\end{array}$ & $\begin{array}{l}\text { VAF } \\
- \\
22.73 \\
\%\end{array}$ & 0.719 & 0.462 \\
\hline 9 & $\begin{array}{l}\text { Perkembangan } \\
\text { identitas } \\
\text { Perencanaan Karier - } \\
\text { > Intensi turnover }\end{array}$ & $\begin{array}{l}\text { VAF } \\
39.19 \\
\%\end{array}$ & 2.915 & 0.001 \\
\hline $\begin{array}{l}1 \\
0\end{array}$ & $\begin{array}{l}\text { Perkembangan } \\
\text { identitas } \\
\text { Resiliensi Karier -> } \\
\text { Intensi turnover }\end{array}$ & $\begin{array}{l}\text { VAF } \\
51.79 \\
\%\end{array}$ & 3.416 & 0.004 \\
\hline
\end{tabular}

Berdasarkan hasil analisis yang di rangkum pada tabel 1 kita dapat mengetahui signifikansi pengaruh pada model (Hair, et al., 2017) dengan syarat signifikansi berdasarkan acuan $t>1.96$ atau $\mathrm{p}<0.05$. Sedangkan syarat acuan mediasi Berdasarkan Wong (2015) nilai VAF lebih besar dari $80 \%$ menandakan mediasi penuh sedangkan nilai VAF antara 20\%-80\% menandakan mediasi parsial.

Perkembangan identitas berpengaruh secara positif terhadap identitas karier secara signifikan dengan nilai $\mathrm{T}=9.727 \mathrm{p}=0.000$. Perkembangan identitas berpengaruh secara positif terhadap perencanaan karier secara signifikan dengan nilai $\mathrm{T}=6.975 \quad \mathrm{p}=0.000 . \quad$ Perkembangan identitas berpengaruh secara positif terhadap resiliensi karier secara signifikan dengan nilai $\mathrm{T}=3.723 \mathrm{p}=0.000$.

Hasil analisa juga menunjukkan bahwa identitas karier tidak berpengaruh secara signifikan 
terhadap intensi turnover dengan nilai $\mathrm{T}=0.739$ $\mathrm{p}=0.460$. Perencanaan karier berpengaruh secara positif terhadap intensi turnover secara signifikan dengan nilai $\mathrm{T}=3.062 \mathrm{p}=0.002$. Resiliensi karier berpengaruh secara positif terhadap intensi turnover secara signifikan dengan nilai $\mathrm{T}=8.863 \mathrm{p}=0.000$.

Dalam analisa juga ditemukan bahwa perkembangan identitas berpengaruh secara positif terhadap intensi turnover secara signifikan dengan $\mathrm{T}=2.021 \mathrm{p}=0.044$.

Kita juga dapat mengetahui kekuatan pengaruh antar variabel independen terhadap variabel dependen secara efek total (Hair et al., 2017). Secara efek total perkembangan identitas berpengaruh secara positif terhadap identitas karier sebesar $49.4 \%$. Secara efek total perkembangan identitas berpengaruh secara positif terhadap perencanaan karier sebesar 39.2\%. Secara efek total perkembangan identitas berpengaruh secara positif terhadap resiliensi karier sebesar $28.4 \%$. Secara efek total perencanaan karier berpengaruh secara positif terhadap intensi turnover sebesar $22.1 \%$. Secara efek total resiliensi karier berpengaruh secara positif terhadap intensi turnover sebesar $50.8 \%$. Secara efek total perkembangan identitas berpengaruh secara positif terhadap intensi turnover sebesar $13.5 \%$.

Dapat disimpulkan bahwa keberhasilan perkembangan identitas memiliki pengaruh positif terhadap identitas karier, perencanaan karier dan resiliensi karier (Seluruh dimensi komitmen karier). Berdasarkan pengujian hipotesis dapat disimpulkan bahwa $\mathrm{H} 1, \mathrm{H} 2$ dan $\mathrm{H} 3$ didukung.

Dapat disimpulkan bahwa terdapat pengaruh positif antar perencanaan karier dan resiliensi karier terhadap intensi turnover, serta tidak terdapat pengaruh antar identitas karier terhadap intensi turnover. Berdasarkan pengujian hipotesis dapat disimpulkan bahwa $\mathrm{H} 4$ tidak didukung, sedangkan H5 dan H6 didukung.

Dapat disimpulkan bahwa keberhasilan perkembangan identitas memiliki pengaruh positif terhadap intensi turnover. Berdasarkan pengujian hipotesis dapat disimpulkan bahwa $\mathrm{H} 7$ didukung.

Dapat disimpulkan bahwa tidak ada mediasi yang signifikan pada pengaruh perkembangan identitas terhadap intensi turnover dengan identitas karier sebagai variabel mediasi dengan nilai $\mathrm{VAF}=-$ $22.73 \% \mathrm{p}=0.462$. Perkembangan identitas mempengaruhi intensi turnover dengan perencanaan karier sebagai variabel mediasi parsial secara signifikan dengan nilai $\mathrm{VAF}=39.19 \% \quad \mathrm{p}=0.001$. Perkembangan identitas mempengaruhi intensi turnover dengan resiliensi karier sebagai variabel mediasi parsial secara signifikan dengan nilai $\mathrm{VAF}=51.79 \% \quad \mathrm{p}=0.004$. Berdasarkan pengujian hipotesis dapat disimpulkan bahwa $\mathrm{H} 8$ tidak didukung , sementara H9 dan H10 didukung.

Pembahasan

Hasil penelitian di atas dapat dijelaskan berdasarkan temuan pada penelitian sebelumnya. Adams dan Marshall (1996) (dalam Crocetti et al., 2004) menyatakan bahwa identitas menyediakan individu dengan struktur sehingga dapat memahami informasi yang relevan dengan diri. Sementara London dan Noe (1997) menjelaskan bahwa identitas karier adalah sejauh mana seseorang mendefinisikan dirinya sendiri dengan pekerjaannya. Oleh karena identitas menyediakan individu dengan struktur sehingga dapat memahami informasi yang relevan dengan diri, identitas tersebut akan menyebabkan seseorang dapat mendefinisikan dirinya sendiri dengan pekerjaannya. Maka dari itu, dalam penelitian ini dibuktikan bahwa perkembangan identitas mempengaruhi identitas karier secara positif. Perkembangan identitas yang mempengaruhi identitas karier dalam penelitian ini juga memperjelas penelitian sebelumnya yang pernah dilakukan oleh Sabanciogullari dan Dogan (2015) yang menyatakan bahwa identitas professional terinkorporasi ke dalam identitas personal seseorang karena seseeorang umumnya menginternalisasi pengetahuan, keterampilan, sikap, nilai dan standar etika dari identitas profesionalnya ke dalam identitas personalnya.

Sementara itu London dan Noe (1997) juga menjelaskan perencanaan karier yang adalah kemampuan untuk bersikap realistis tentang diri dan kariernya dalam penetapan tujuan karier. Identitas juga menyediakan individu dengan Harmonisasi antara nilai, kepercayaan dan komitmen seseorang (Adams \& Marshall, 1996 dalam Crocetti et al., 2004). Terlebih lagi Erikson dalam Nauta dan Kahn (2007) menyatakan bahwa perkembangan identitas penting bagi keputusan karier karena menyangkut keterlibatan akan eksplorasi diri serta dunia. Identitas tersebut akan membuat seseorang dapat untuk bersikap realistis tentang diri dan kariernya sehingga dapat menggunakan persepsi tersebut untuk penetapan tujuan karier. Maka dari itu, dalam penelitian ini dibuktikan bahwa perkembangan identitas mempengaruhi perencanaan karier secara positif.

London dan Noe (1997) juga menjelaskan resiliensi karier sebagai ketekunan dalam beradaptasi dengan perubahan bagi pencapaian tujuan karier. Oleh karena identitas menyediakan orientasi atau arah akan masa depan serta kesinambungan antara masa lalu, sekarang dan masa depan (Adams \& Marshall, 1996 dalam Crocetti et al., 2004). Terlebih lagi identitas menyangkut pembuatan komitmen yang berhubungan dengan identitas (Erikson dalam Nauta \& Kahn, 2007). Maka dengan orientasi atau arah akan masa depan yang jelas, seseorang dapat tekun untuk mencapai tujuan karier yang telah ditentukannya. Maka dari itu, dalam penelitian ini dibuktikan bahwa perkembangan identitas mempengaruhi resiliensi karier secara positif.

Hasil penelitian yang membuktikan bahwa 
perkembangan identitas mempengaruhi perencanaan karier, identitas karier, dan resiliensi karier sebagai dimensi dari komitmen karier sejalan dengan penelitian sebelumnya yang menyatakan adanya korelasi antar perkembangan identitas dan komitmen karier (Grotevant \& Thorbecke, 1982). Hal ini dapat dijelaskan oleh Trisnawati (2012) yang menyatakan bahwa perkembangan identitas seseorang yang baik akan menyebabkan orang tersebut mantap dalam menentukan karier. Nauta dan Kahn (2007) juga menyatakan hal yang serupa bahwa identitas yang terdefinisikan membentuk gambaran yang jelas dan stabil sehingga memiliki pengambilan keputusan karier dan minat karier yang konsisten.

Dalam penelitian ini dibuktikan terdapat pengaruh positif antar perencanaan karier dan resiliensi karier terhadap intensi turnover, serta tidak terdapat pengaruh antar identitas karier terhadap intensi turnover. Hasil dalam penelitian ini bertentangan dengan penelitian dan pendapat para ahli di bab satu dan dua.

Sumber sebelumnya tersebut menyatakan bahwa komitmen karier mempengaruhi intensi turnover secara negatif (Bedeian et al., 1991); (Li, 2018). Hal tersebut sesuai dengan teori dan penelitian sebelumnya oleh Ingarianti et al. (2019) yang menyatakan bahwa komitmen karier menyebabkan seseorang tetap bekerja di organisasi tempat ia bekerja terlepas dari rekan sepekerja, kondisi kerja, maupun ketidakpuasan organisasi tempat ia bekerja. Serta juga sesuai dengan penelitian lainnya yang menyatkan hal serupa, bahwa komitmen karier menyebabkan seseorang terikat dengan pekerjaannya walau tidak puas dengan pekerjaannya karena seseorang tersebut menganggap pekerjaan tersebut relevan terhadap karier yang dimiliki (Mobley dalam Bedeian, (Bedeian et al., 1991).

Namun pengaruh yang positif antar perencanaan karier dan resiliensi karier sebagai dimensi dari komitmen karier terhadap intensi turnover dalam penelitian ini dapat dijelaskan oleh beberapa teori lainnya. Bahwa komitmen karier dipandang sebagai motivasi dalam bekerja di pilihan karier yang melibatkan perasaan perihal kompetensi serta kemungkinan sukses dalam menjalani pilihan karier (Hall dalam Ingarianti, 2017). Motivasi tersebut mendorong individu dalam pencapaian tujuan karier serta kemajuan pribadi (Ellemers, et al. dalam Ingarianti, 2017). Berdasarkan teori tersebut mungkin saja organisasai tempat individu bekerja saat ini tidak memberikan pencapaian tujuan karier serta kemajuan pribadi individu, sehingga individu termotivasi untuk mencapai tujuan karier serta kemajuan pribadi dengan mempertimbangkan berkarya di organisasi lain.

Hal ini sejalan dengan pernyataan Menteri Ketenagakerjaan (dalam CNN Indonesia, 2020) yang menyatakan bahwa di Indonesia kurang dari 10 persen perusahaan memberikan pelatihan formal. Salah satu pelatihan formal karyawan adalah program pengembangan karier, bagi karyawan program pengembangan karier memberikan gambaran jalurjalur karir di masa depan dalam organisasi serta menandakan kepentingan secara jangka panjang dari organisasi terhadap karyawan (Jumawan \& Mora, 2018). Dalam pelaksanaan program pengembangan karier organisasi meningkatkan pengembangan karier dari masing-masing karyawan tersebut (Jumawan \& Mora, 2018). Bahkan pengembangan karier dalam perusahaan berkontribusi secara negatif sebesar 9\% terhadap intensi turnover (Putra et al., 2020). Penjelasan dengan teori-teori di atas juga didukung oleh Mellor et.al. (dalam Cicek et al., 2016) yang menyatakan bahwa komitmen karir individu yang tinggi tidak mengharuskan komitmen organisasi yang tinggi juga.

Mengenai dimensi identitas karier yang merupakan salah satu dimensi dari komitmen karier yang tidak mempengaruhi intensi turnover secara signifikan, dapat dijelaskan dalam teori dan penelitian sebelumnya. Becker dalam Carson (1991) menyatakan bahwa komitmen karier dimotivasi oleh identitas karier yang dimiliki seseorang. Walaupun begitu, identitas karier dinilai tidak cukup bagi operasionalisasi multi dimensi dari komitmen karier (Carson, 1991). Hal ini disebabkan karena dimensi teoretis dari identitas karier, komitmen karier tidak berkaitan dengan keberlangsungan karier, melainkan berkaitan dengan afeksi terhadap komitmen (London dalam Carson, 1991). Oleh karena itu identitas karier saja tidak cukup bagi operasionalisasi multi dimensi dari komitmen karier (Carson, 1991). Hal ini disebabkan karena seseorang yang berkomitmen terhadap karier harus menunjukkan determinasi (Lee, Locke \& Latham dalam Carson, 1991) beserta stabilitas (Van Maanen \& Schein dalam Carson, 1991) yang dapat dicapai melalui perencanaan karier dan resiliensi karier (London dalam Carson, 1991). Maka dari itu, identitas karier sebagai dimensi dari komitmen karier yang lebih bersifat afeksi (Pasif) daripada keberlangsungan (Aktif) mungkin menyebabkan identitas karier tidak mempengaruhi intensi turnover .

Dalam penelitian ini dibuktikan bahwa identitas mempengaruhi intensi turnover melalui seluruh mediasi secara bersamaan. Terdapat pengaruh positif dan signifikan antar identitas terhadap intensi turnover melalui seluruh mediasi secara bersamaan. Walaupun dalam penelitian ini terdapat bukti akan pengaruh posiif, namun hasil dalam penelitian ini bertentangan dengan penelitian sebelumnya dan pendapat para ahli. Penelitian sebelumnya dan pendapat para ahli menunjukkan pengaruh negatif antar identitas terhadap intensi turnover.

Penelitian sebelumnya oleh Deng et al. (2020) yang menggunakan variabel identitas okupasional, yang konstruknya berasal dari variabel perkembangan identitas, menyatakan bahwa identitas okupasional berpengaruh negatif terhadap intensi 
turnover. Hasil penelitian tersebut sesuai dengan penelitian lainnya yang dilakukan oleh Sabanciogullari dan Dogan (2015) yang menyatakan bahwa individu yang memiliki identitas yang konsisten dengan kariernya akan mencurahkan lebih banyak energi dan lebih bersemangat untuk bekerja sehingga ketidakpuasan oleh lingkungan kerja akan dihilangkan sampai batas tertentu. Selain itu Britt (2003) juga menyatakan hal yang serupa bahwa jika aspek-aspek dari identitas individu tersebut konsisten dengan pekerjaannya maka individu dapat mempertahankan tingkat keterlibatan kerja yang tinggi, terlepas dari baik atau buruknya kondisi kerja.

Hasil penelitian di penelitian ini berbeda dengan penelitian-penelitian sebelumnya. Pengaruh yang positif antar indentitas terhadap intensi turnover dalam penelitian ini dapat dijelaskan oleh beberapa teori di paragraf selanjutnya, walaupun tidak bisa dijelaskan oleh hasil penelitian sebelumnya karena penelitian dengan kedua variabel spesifik ini belum pernah dilakukan.

Identitas menyediakan harmonisasi antara nilai, kepercayaan dan komitmen bagi individu (Adams \& Marshall, 1996 dalam Crocetti et al., 2004). Identitas juga membentuk gambaran yang jelas dan stabil sehingga individu memiliki konsistensi pengambilan keputusan karier dan minat karier (Nauta \& Kahn, 2007). Oleh karena perkembangan identitas terjadi sepanjang masa hidup (Erikson dalam Karaś et al., 2014), dalam mengembangkan identitas tersebut individu mengeksplorasi dan merefleksikan dirinya untuk menemukan kelanjutan (Muss dalam Karcher \& Benne, 2007).

Berdasarkan sumber sebelumnya tersebut dapat disimpulkan bahwa individu yang memiliki keberhasilan perkembangan identitas memiliki konsistensi pengambilan keputusan karier dan minat karier, serta memiliki nilai, kepercayaan dan komitmen untuk mengembangkan karirnya secara konsisten untuk menemukan kelanjutan. Untuk menemukan kelanjutan tersebut, sangat mungkin bahwa individu yang memiliki konsistensi pengambilan keputusan karier dan minat karier, serta memiliki nilai, kepercayaan dan komitmen untuk mengembangkan karirnya memutuskan untuk pindah dari organisasi tempat individu bekerja. Terutama jika organisasi tersebut dinilai individu tidak memberikan pengembangan karier sesuai nilai, kepercayaan dan komitmen individu. Terutama, Menteri Ketenagakerjaan dalam CNN Indonesia (2020) menyatakan bahwa dibandingkan dengan negaranegara tetangga, di Indonesia perusahaan sangat kurang memberikan pelatihan formal, yakni tidak sampai 10 persen.

Ditambah lagi, perkembangan identitas menyangkut keterlibatan akan eksplorasi diri serta eksplorasi dunia (Erikson dalam Nauta \& Kahn, 2007). Oleh karena itu, jika organisasi tempat individu bekerja tidak lagi membuat individu terlibat akan eksplorasi diri serta eksplorasi dunia, mungkin saja individu tersebut akan mencari organisasi lain.

Dalam pelatihan seperti program pengembangan karier, organisasi akan meningkatkan karier dari karyawan yang ada di organisasi tersebut (Jumawan \& Mora, 2018). Bahkan penelitian lainnya menyatakan bahwa pengembangan karier dalam perusahaan berkontribusi secara negatif terhadap intensi turnover sebesar 9\% (Putra et al., 2020).

Teori-teori ahli di atas juga dapat menjelaskan hasil penelitian mengenai mediasi dalam penelitian ini. Terlebih lagi penelitian sebelumnya yang menggunakan variabel serupa sebagai variabel mediasi belum pernah dilakukan sehingga pembahasan berdasarkan hasil penelitian terdahulu tidak dapat dilakukan. Oleh karena itu pembahasan dilakukan dengan mengacu teori ahli.

Identitas karier dinilai tidak cukup bagi operasionalisasi multi dimensi dari komitmen karier (Carson, 1991). Dimensi teoretis dari identitas karier tidak berkaitan dengan keberlangsungan karier, melainkan berkaitan dengan afeksi terhadap komitmen (London dalam (Carson, 1991). Identitas karier yang dinilai tidak berkaitan dan bersifat pasif terhadap keberlangsungan karier tersebut dapat menjelaskan hasil penelitian mengenai tidak adanya mediasi yang signifikan pada pengaruh perkembangan identitas terhadap intensi turnover dengan identitas karier sebagai variabel mediasi. Tidak ada mediasi yang signifikan berarti jalur antara variabel perkembangan identitas dan variabel intensi turnover tidak terpengaruh sama sekali jika memperhitungkan variabel mediasi identitas karier.

Menurut pendapat ahli lainnya determinasi (Lee, Locke \& Latham dalam Carson, 1991) dan stabilitas (Van Maanen \& Schein dalam Carson, 1991) yang keduanya tergambarkan melalui perencanaan karier dan resiliensi karier (London dalam Carson, 1991) ditunjukkan oleh orang yang berkomitmen terhadap kariernya. Komitmen karier merupakan motivasi dalam bekerja di pilihan karier yang melibatkan perasaan perihal kompetensi serta kemungkinan sukses dalam menjalani pilihan karier (Hall dalam Ingarianti, 2017). Motivasi tersebut mendorong individu dalam pencapaian tujuan karier serta kemajuan pribadi (Ellemers, et al. dalam Ingarianti, 2017). Jika organisasi individu tidak menyediakan pencapaian tujuan karier serta kemajuan pribadi bagi dari individu, individu tersebut harus keluar dari organisasi tempat ia bekerja untuk mencapai tujuan karier serta kemajuan pribadi.

Berkaitan dengan resiliensi karier, Seery, Holman, dan Silver (2010) (dalam Rossier et al., 2017) menyatakan bahwa resiliensi karier adalah kemampuan untuk beradaptasi yang berkaitan dengan paparan berulang dan adaptasi yang berhasil terhadap kesulitan. Individu dengan resiliensi karier cenderung menjaga kesehatan fisik dan psikologisnya dengan menghadapi peristiwa negatif dengan cara yang 
memuaskan pada saat-saat yang menantang sembari meningkatkan kesejahteraan mereka (Rossier et al., 2017). Upaya individu dengan resiliensi karier untuk menghadapi peristiwa negatif dengan cara yang memuaskan pada saat-saat yang menantang sembari meningkatkan kesejahteraan dapat berarti individu tersebut pindah dari organisasi tempat ia bekerja saat ini.

Berkaitan dengan perencanaan karier, Chetana dan Mohapatra (2017) menyatakan lima tahap dari proses perencanaan karier : (1) penilaian diri, (2) menyelidiki peluang karier, (3) penetapan tujuan, (4) perencanaan tindakan, dan (5) evaluasi. Rizanuddin (2020) menambahkan bahwa dalam upaya perencanaan karier individu mempertimbangkan situasi, baik internal maupun eksternal organisasi. Maka dari itu, individu yang memiliki perencanaan karier yang baik mungkin mempertimbangkan eksternal organisasi, atau dalam artian lain pindah dari organisasi tempat ia bekerja saat ini.

Oleh karena itu dalam penelitian ini ditemukan bahwa perkembangan identitas mempengaruhi intensi turnover secara positif dan signifikan dengan perencanaan karier sebagai variabel mediasi parsial. Selain itu, dalam penelitian ini ditemukan bahwa perkembangan identitas mempengaruhi intensi turnover turnover secara positif dan signifikan dengan resiliensi karier sebagai variabel mediasi parsial. Variabel parsial tersebut menyatakan bahwa saat variabel mediator perencanaan karier dan resiliensi karier diperhitungkan, jalur antara variabel perkembangan identitas terhadap intensi turnover berkurang secara absolut namun jauh dari nilai nol.

Dalam arti lain perkembangan identitas tidak bergantung sepenuhnya pada variabel mediasi (Perencanaan karier dan resiliensi karier) dalam mempengaruhi intensi turnover secara signifikan. Berdasarkan teori hal ini disebabkan oleh karena pengaruh perkembangan identitas yang mumpuni terhadap intensi turnover. Seseorang yang memiliki tingkat keberhasilann perkembangan identitas yang tinggi memiliki gambaran yang jelas dan stabil sehingga individu memiliki konsistensi pengambilan keputusan karier dan minat karier (Nauta \& Kahn, 2007). Dalam mengembangkan identitasnya, Muss dalam Karcher dan Benne, (2007) menyatakan bahwa seseorang mengeksplorasi dan merefleksikan dirinya untuk menemukan kelanjutan. Berdasarkan teori yang dikemukakan ahli tersebut, dapat disimpulkan bahwa dalam mengembangkan identitasnya seseorang berusaha untuk mengeksplorasi dan merefleksikan diri untuk menemukan kelanjutan. Oleh karena perkembangan identitas menyangkut keterlibatan akan eksplorasi diri serta eksplorasi dunia (Erikson dalam Nauta \& Kahn, 2007) Dalam menemukan kelanjutan tersebut mungkin saja individu memutuskan untuk pindah dari organisasi tempatnya bekerja dalam mengeksplorasi diri serta dunia.

\section{Kesimpulan}

Berdasarkan analisis yang telah dilakukan, maka disimpulkan :

1. Keberhasilan perkembangan identitas memiliki pengaruh positif dan signifikan terhadap identitas karier.

2. Keberhasilan perkembangan identitas memiliki pengaruh positif dan signifikan terhadap perencanaan karier.

3. Keberhasilan perkembangan identitas memiliki pengaruh positif dan signifikan terhadap resiliensi karier.

4. Identitas karier tidak mempengaruh intensi turnover secara signifikan.

5. Perencanaan karier memiliki pengaruh positif dan signifikan terhadap intensi turnover.

6. Resiliensi karier memiliki pengaruh positif dan signifikan terhadap intensi turnover.

7. Keberhasilan perkembangan identitas memiliki pengaruh positif dan signifikan terhadap intensi turnover.

8. Identitas karier sebagai variabel mediasi tidak signifikan pada pengaruh perkembangan identitas terhadap intensi turnover.

9. Keberhasilan perkembangan identitas memiliki pengaruh positif dan signifikan terhadap intensi turnover dengan mediasi parsial perencanaan karier pada karyawan milenial di wilayah Jabodetabek.

10. Keberhasilan perkembangan identitas memiliki pengaruh positif dan signifikan terhadap intensi turnover dengan mediasi parsial resiliensi karier pada karyawan milenial di wilayah Jabodetabek.

Berdasarkan hasil penelitian, sangat mungkin organisasai tempat individu bekerja saat ini tidak memberikan pencapaian tujuan karier serta kemajuan pribadi individu, sehingga individu termotivasi untuk mencapai tujuan karier serta kemajuan pribadi dengan mempertimbangkan berkarya di organisasi lain. Hal ini sejalan dengan pernyataan Menteri Ketenagakerjaan dalam CNN Indonesia (2020) yang menyatakan bahwa di Indonesia kurang dari 10 persen perusahaan memberikan pelatihan formal.

Penelitian ini adalah penelitian pertama yang menguji variabel perkembangan identitas Erikson dan variabel intensi turnover, juga penelitian pertama yang menguji variabel perkembangan identitas Erikson dan variabel komitmen karier. Dalam penelitian ini diketahui bahwa perkembangan identitas memiliki pengaruh positif dan signifikan terhadap intensi turnover. Seluruh kesimpulan hasil analisa setiap variabel yang didukung oleh teori serta penelitian sebelumnya mengindikasikan bahwa pengaruh positif terhadap intensi turnover mungkin disebabkan oleh pelatihan karier yang kurang di perusahaan-perusahaan di indonesia. Walaupun 
begitu, indikasi tersebut tidaklah konkrit karena belum terbukti dalam penelitian, maka dari itu disarankan agar penelitian selanjutnya dapat membahas perihal ini dengan rinci.

Dalam penelitian ini, seluruh kesimpulan hasil analisa yang didukung oleh teori serta penelitian sebelumnya mengindikasikan bahwa terdapat pengaruh positif perkembangan identitas terhadap intensi turnover. Walau begitu, keberhasilan perkembangan identitas pada responden dalam penelitian ini belum diteliti tingkat keberhasilannya tinggi atau rendah, sehingga disarankan untuk dijadikan bahan untuk penelitian selanjutnya.

Selain itu, keberhasilan perkembangan identitas akan sangat menarik dan disarankan untuk diteliti secara longitudinal di penelitian selanjutnya karena berdasarkan Erikson (dalam Karaś et al., 2014) tahapan perkembangan identitas adalah tugas pengembangan yang utama dalam kehidupan.

\section{Referensi}

APJII. (2017). Penetrasi \& Perilaku Pengguna Internet Indonesia. https://web.kominfo.go.id/ sites/default/files/Laporan Survei APJII_2017 _v1.3.pdf

Apriyono, A. (2017). Riset: Tingkat Kesetiaan Karyawan Generasi Milenial Paling Rendah. Liputan6.Com.

Bedeian, A. G., Kemery, E. R., \& Pizzolatto, A. B. (1991). Career commitment and expected utility of present job as predictors of turnover intentions and turnover behavior. Journal of Vocational Behavior, 39(3). https://doi.org/ 10.1016/0001-8791(91)90042-K

Blau, G. (1989). Testing the generalizability of a career commitment measure and its impact on employee turnover. Journal of Vocational Behavior, 35(1). https://doi.org/10.1016/00018791(89)90050-X

Britt, T. W. (2003). Aspects of Identity Predict Engagement in Work Under Adverse Conditions. Self and Identity, 2(1). https://doi.org/10.1080/15298860309022

Carson, K. D. (1991). A Multidimensional Career Commitment Measure (MCCM) Gauging Motivation to Work in One's Career Field. LSU Historical Dissertations and Theses.

Carson, K. D., \& Bedeian, A. G. (1994). Career commitment: Construction of a measure and examination of its psychometric properties. Journal of Vocational Behavior, 44(3). https://doi.org/10.1006/jvbe.1994.1017

Chetana, N., \& Mohapatra, A. K. Das. (2017). Career planning and career management as antecedents of career development: A study. Asian Journal of Management, 8(3). https://doi.org/10.5958/2321-

5763.2017.00098.1

Cicek, I., Karaboga, T., \& Sehitoglu, Y. (2016). A New Antecedent of Career Commitment: Work to Family Positive Enhancement. Procedia - Social and Behavioral Sciences, 229. https://doi.org/10.1016/j.sbspro.2016.07.152

CNN Indonesia. (2020). Menaker Sebut Perusahaan RI Kurang Latih Karyawan. https://www.cnnindonesia.com/ekonomi/2020 0207112410-92-472546/menaker-sebutperusahaan-ri-kurang-latih-karyawan

Crocetti, E., Avanzi, L., Hawk, S. T., Fraccaroli, F., \& Meeus, W. (2004). Personal and Social Facets of Job Identity: A Person-Centered Approach. Journal of Business and Psychology, 29(2). https://doi.org/10.1007/s10869-013-9313-x

Deloitte Indonesia Perspectives. (2019). Generasi Milenial dalam Industri 4.0: Berkah Bagi Sumber Daya Manusia Indonesia atau Ancaman? Deloitte Indonesia, 1.

Deng, W., Feng, Z., Yao, X., Yang, T., Jiang, J., Wang, B., Lin, L., Zhong, W., \& Xia, O. (2020). Occupational identity, job satisfaction and their effects on turnover intention among Chinese Paediatricians: a cross-sectional study. BMC Health Services Research, 21(1). https://doi.org/10.1186/s12913-020-05991-z

Donoughue, P. (2017). Are we raising a generation of unhappy, non-resilient young people? http://www.abc.net.au/news/2017-09-20/teenssmartphones-resilience-adulthood/8960618

Ekrut. (2020). Kenali perbedaan generasi milenial dan generasi $Z$ dalam dunia kerja.

Folia, R. (2020). 11 Alasan Mengapa Millennial Mudah Pindah Kerja.

Grotevant, H. D., \& Thorbecke, W. L. (1982). Sex differences in styles of occupational identity formation in late adolescence. Developmental Psychology, 18(3). https://doi.org/10.1037/0012-1649.18.3.396

Hair, J. F., Hult, G. T. M., Ringle, C. M., \& Sarstedt, M. (2017). A Primer on Partial Least Squares Structural Equation Modeling (PLS-SEM). Second Edition. In California: Sage.

Holland, J. L., Johnston, J. A., Johnston, J. A., \& Asama, N. F. (1993). The Vocational Identity Scale: A Diagnostic and Treatment Tool. Journal of Career Assessment, 1(1). https://doi.org/10.1177/106907279300100102

Ingarianti, T. M. (2017). Faktor-Faktor Yang Mempengaruhi Komitmen Karier. Jurnal Ilmiah Psikologi Terapan, 5(2). https://doi.org/10.22219/jipt.v5i2.4935

Ingarianti, T. M., Fajrianthi, F., \& Purwono, U. (2019). Adaptasi Alat Ukur Komitmen Karier. Jurnal Psikologi, 18(2). https://doi.org/ 10.14710/jp.18.2.199-217 
Jumawan, J., \& Mora, M. T. (2018). Pengaruh Pelatihan Dan Pengembangan Karier Terhadap Kinerja Karyawan Perusahaan Korporasi. Jurnal Riset Manajemen Dan Bisnis (JRMB) Fakultas Ekonomi UNIAT, 3(3). https://doi.org/10.36226/jrmb.v3i3.153

Karaś, D., Cieciuch, J., Negru, O., \& Crocetti, E. (2014). Relationships Between Identity and Well-Being in Italian, Polish, and Romanian Emerging Adults. Social Indicators Research, 121(3). https://doi.org/10.1007/s11205-0140668-9

Karcher, M. J., \& Benne, K. (2007). Erik and Joan Erikson's approach to human development in counseling. In Lifespan development in action: A case study approach for counseling professionals.

Keil, F. C. (2014). Developmental Psychology The Growth of Mind and Behavior. In W.W. Norton \& Company.

Lakshmi, P. A. V., \& Sumaryono, S. (2019). Kesuksesan Karier Ditinjau dari Persepsi Pengembangan Karier dan Komitmen Karier pada Pekerja Milenial. Gadjah Mada Journal of Psychology (GamaJoP), 4(1). https://doi.org/10.22146/gamajop.45782

Lally, M., \& Valentine-French, S. (2017). Lifespan Development: A Psychological Perspective. In PsycCRITIQUES.

Latipah, E. (2012). Metode Penelitian Psikologi (Vol. 1, Issue 1). Deepublish.

Li, Y. F. (2018). Career Growth And Turnover Intention: The Mediator Role Of Career Commitment And Organizational Identification. https://repositorio.iscte-iul.pt/ bitstream/10071/17551/1/master_li_yifei.pdf

London, M., \& Noe, R. A. (1997). Londons Career Motivation Theory: An Update on Measurement and Research. Journal of Career Assessment, 5(1), 61-80. https://doi.org/ $10.1177 / 106907279700500105$

Mazalin, D., \& Moore, S. (2004). Internet use, identity development and social anxiety among young adults. Behaviour Change, 21(2). https://doi.org/10.1375/bech.21.2.90.55425

Meyer, J. P., Stanley, D. J., Herscovitch, L., \& Topolnytsky, L. (2002). Affective, continuance, and normative commitment to the organization: A meta-analysis of antecedents, correlates, and consequences Journal of Vocational Behavior, 61(1). https://doi.org/10.1006/jvbe.2001.1842

Mobley, W. H. (1977). Intermediate linkages in the relationship between job satisfaction and employee turnover. Journal of Applied Psychology, 62(2). https://doi.org/10.1037/ 0021-9010.62.2.237

Mulyapradana, A. (2012). Hubungan Kebijakan Pengembangan Karir Terhadap Intensi
Turnover Karyawan Di Divisi Marketing PT

Agromedia. Universitas Indonesia.

https://library.ui.ac.id/detail?id=20302596\&lo kasi=lokal

Nauta, M. M., \& Kahn, J. H. (2007). Identity status, consistency and differentiation of interests, and career decision self-efficacy. Journal of Career Assessment, 15(1). https://doi.org/10. 1177/1069072705283786

Putra, A. I. D., Lie, V., \& Alvani, S. (2020). Pengaruh Pengembangan Karier Terhadap Intensi Turnover di PT Benua Penta Global Medan. Insight : Jurnal Pemikiran Dan Penelitian Psikologi, 16(1). https://doi.org/10. 32528/ins.v16i1.2005

Ringle, C. M. (2018). Sample size: minimum R2 method.

Rizanuddin, H. (2020). Influences of Career Planning, Leadership and Organizational Culture towards Employee Work Effectiveness. Budapest International Research and Critics Institute (BIRCIJournal): Humanities and Social Sciences, 3(3). https://doi.org/10.33258/birci.v3i3.1112

Rosenthal, D. A., Gurney, R. M., \& Moore, S. M. (1981). From trust on intimacy: A new inventory for examining erikson's stages of psychosocial development. Journal of Youth and Adolescence, 10(6). https://doi.org/10. 1007/BF02087944

Ross, K. W. (2017). Applying career and identity development theories in advising.

Rossier, J., Ginevra, M. C., Bollmann, G., \& Nota, L. (2017). The importance of career adaptability, career resilience, and employability in designing a successful life. In Psychology of Career Adaptability, Employability and Resilience. https://doi.org/ 10.1007/978-3-319-66954-0_5

Sabanciogullari, S., \& Dogan, S. (2015). Relationship between job satisfaction, professional identity and intention to leave the profession among nurses in Turkey. Journal of Nursing Management, 23(8). https://doi.org/10.1111/jonm.12256

Schultz, D., \& Schultz, S. (2009). Theories of personality (9th ed.). 9Th $E d$.).

Schwartz, S. J., Côté, J. E., \& Arnett, J. J. (2005). Identity and agency in emerging adulthood: Two developmental routes in the individualisation process. Youth and Society, $37(2)$. https://doi.org/10.1177/0044118X05275965

Schwartz, S. J., Zamboanga, B. L., Weisskirch, R. S., \& Rodriguez, L. (2009). The relationships of personal and ethnic identity exploration to indices of adaptive and maladaptive psychosocial functioning. International Journal of Behavioral Development, 33(2). https://doi.org/10.1177/0165025408098018 
Siyoto, S dan Sodik, M. A. (2015). Dasar Metodologi Penelitian Cetakan Pertama. Literasi Medika, 66(February).

Society for the Study of Emerging Adulthood (SSEA). (2016). Overview. http://ssea.org/about/index.htm

Suliyanto. (2006). Metode Riset Bisnis. Andi.

Tim Website UNY. (2017). Era Digital Membuat Netizen Krisis Identitas.

Trisnawati. (2012). Hubungan antara persepsi terhadap peran dosen laboratorium minat dengan kemantapan karir mahasiswa Fakultas Psikologi Universitas Surabaya. Calyptra, l(1), 1-8.

Vondracek, F. W., Schulenberg, J., Skorikov, V., Gillespie, L. K., \& Wahlheim, C. (1995). The relationship of identity status to career indecision during adolescence. Journal of Adolescence, 18(1). https://doi.org/10.1006/jado.1995.1003

Wilson, M. E., Liddell, D. L., Hirschy, A. S., \& Pasquesi, K. (2016). Professional identity, career commitment, and career entrenchment of midlevel student affairs professionals. Journal of College Student Development, 57(5). https://doi.org/10.1353/csd.2016.0059 